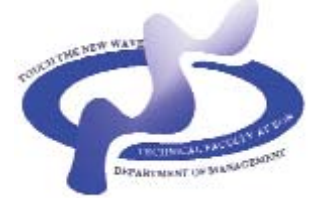

www.sjm06.com

\title{
IMPACT OF ENVIRONMENTAL FACTORS ON THE EFFICIENCY OF TAX ORGANIZATIONS
}

\author{
Marios Tsakas $^{a^{*}}$ and Maria Katharaki ${ }^{b}$

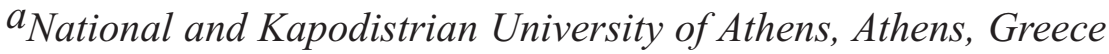

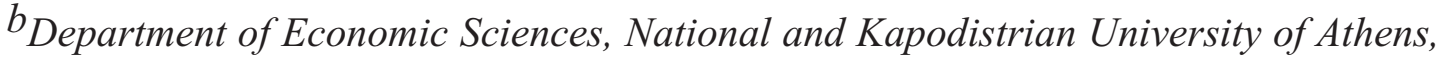 \\ Athens, Greece
}

(Received 11 August 2013; accepted 23 January 2014)

\begin{abstract}
The study examines the performance of tax organizations in Greece, based on data obtained from a sample of 35 tax offices. Performance evaluation was conducted using DEA with bootstrap methods. In addition, Tobit regression analysis was employed to examine the environmental variables that impact on the efficiency performance of these tax offices. From the analysis, weaknesses, and management issues are derived from the tax offices inefficiency. The general conclusion is that a robust governance structure within the tax office operational framework is needed in order to improve organisational efficiency.
\end{abstract}

Keywords: Taxation, tax evasion, performance management, Greece, DEA, Bootstrap, Public sector organisations, quantitative methods

\section{INTRODUCTION}

Global financial and economic crisis has brought to the fore the need for assessing public sector performance. Improving the functioning of public sector and enhancing the efficiency of public administration constitute measures taken by governments to cushion the effect of the crisis on their country economies. Equal distribution of public expenditure and taxation countrywide is essentially important for social cohesion

\footnotetext{
* Corresponding author: mtsakas@evolution-isa.gr
}

DOI:10.5937/sjm9-4314 
and sustainable development. Convergence in public expenditure could be used as an indicator of the rational distribution of welfare in all regions; on the other hand, tax revenue convergence is an indicator of the rational distribution of financing of public expenditure. Therefore taxation system efficiency is of pivotal importance to the longevity and well-being of any public sector activity. Increasing the revenues obtained from taxation can be achieved only at progressively higher marginal costs (Afonso et al., 2006). International literature can provide documentary evidence showing that tax offices are indeed coming under increasing scrutiny. Likewise, a number of countries now seek to maximize income by improving the efficiency of tax collection processes through a shake-up of the entire tax office system (Budryte, 2005).

In this context, the current international financial crisis, which has greatly impacted Greek financial activities has also brought to the fore the pathogenesis of the Greek economy, which is mainly structural. One of the main problems of the Greek economy is the functioning of the fraudulent 'informal' economy, which is linked to tax evasion, and therefore leads to complexities and distortions of the mainstream economic reality nationwide. The current economic climate underlines, as ever, the need for efficient tax administration, essential if any tax system is to attain its desired aims. The inefficiency of the tax system is expressed mainly by the amount of tax that is being evaded, high levels of which are attributed to:

- Ineffective tax collection mechanisms and failure to implement methods that would contribute to tax revenue increases; these include approaches aimed at rational handling of tax compliance and systematic monitoring of tax and legal responsibilities;

- Fraudulent practices;

- Low level and minimally trained staff within tax authorities.

The Greek economy, while addressing the impact of the financial crisis, is mainly faced with high debt levels, an unacceptably high deficit, high unemployment, low competitiveness and an inherent inability to collect public revenues. The admitted lag in revenue raising is an indication of the ineffective operation of the tax collection mechanism stemming from and leading towards ever-increasing levels of tax evasion, by now a dominant issue in the context of the severe economic woes plaguing the country. The current levels of tax evasion can be attributed on the one hand to the existing institutional framework of the Internal Revenue system and on the other on the characteristics of the available human resources allocated to the individual tax offices and the socioeconomic environment within which each tax office operates. It therefore becomes evident that there is a pressing need to assess the functioning of the tax office system as a whole.

Literature survey provides documentary evidence showing that tax offices evaluations have to date been carried out using mostly DEA-based methodologies. Katharaki and Tsakas (2010) assessed the performance of 27 tax offices in Greece through the 2001 - 2006 period using DEA, window analysis and the Tobit model. Moesen and Persoon (2002) analysed the efficiency of 289 Belgian tax offices with free disposal hull (FDH) and DEA, while Gonzalez and Miles (2000) analysed the efficiency of 15 Spanish regional tax offices for the year 1995 with DEA, using a bootstrap technique. Thirtle et al. (2000) 
analysed the efficiency of Indian tax offices from 1980-1981 to 1992-1993 using DEA and Malmquist indices. More recently, Barros (2007) assessed the technical and allocative efficiency of tax offices in Portugal, while the same team (2005) used a stochastic evolution model combined with the DEA approach for the evaluation of tax office activity. Forsund, Kittelsen and Lindseth (2005) applied DEA and a Malmquist productivity index for the evaluation of Norwegian tax offices.

In this context, the objective of the current study is firstly to estimate the relative technical efficiency (TE) by using a sample from Greek tax offices aiming to underline management issues that results from the manner in which the tax offices operate; and, secondly to emphasize the policy implications for tax system policy-makers. Considering that tax office evaluation has been limited so far, attributable mainly to the non-disclosure policy of public entities globally (Barros, 2007), the present study aims simply to highlight the importance of the information (without sensationalizing it) from the policymakers perspective and in so doing perhaps provide an additional information resource on which they can base their decisions and policies.

The paper is organized into the following sections:

- section 2 describes the sample selection and analysis plan, while a description of the techniques used to estimate the tax offices efficiency is also presented;

- $\quad$ section 3 provides an outline of the results obtained from the quantitative methods used along with their interpretation;

- $\quad$ section 4 provides a discussion on the managerial implications of the research and concludes with directions for future research.

\section{MATERIAL / METHODS}

The research is based on data collected from official public sources of the Greek Ministry of Economy and Finance spanning the period 2001-2006. The six (6) year duration of the data set is considered adequate for the investigation of the dynamic evolution of tax office performance in each case and its data-based evaluation. The selection of the 35 tax offices that make up the sample (for ethical reasons these will be referred to only as F1, F2, ..., F35) was made from the Attica and Piraeus regions, the wider metropolitan area of the Greek capital in other words, excluding tax offices that cover regions characterised:

- as tourist areas, or else the key characteristic of the regional economy is the operation of numerous tourist facilities;

- by rural economic activities.

The key feature of the tax offices that make up the sample is that their areas of responsibility are identified by the large numbers of taxpayers, but also by the complexity of their economic activities. In summary, the 35 tax offices in the sample covered in 2006, a total of 378,063 taxpayers (natural persons and legal entities), i.e. $19.7 \%$ of the total and earned $3,665,480,640.20$ EUR, which accounts for $11.5 \%$ of total revenue raised by all the tax offices in the country. Table 1 shows the proportion of tax revenues attributed to individuals to those raised by legal entities.

The annual revenue raised for the total number of taxpayers (sum of natural persons and legal entities) for tax office is also shown in Table 1. It should be noted that the maximum annual taxpayer payment was 23,110.04 $€$, paid at F21, while the minimum was 5,926.77 EUR paid at F33, overall representing a spread, the causes of which 
Table 1. Proportion of tax revelues and average annual recovery per tax office (Year 2006)

\begin{tabular}{|c|c|c|c|c|c|}
\hline $\begin{array}{l}\text { Tax } \\
\text { Offices }\end{array}$ & $\begin{array}{l}\text { Ratio of Natural } \\
\text { to Legal entities }\end{array}$ & $\begin{array}{l}\text { Average annual } \\
\text { recovery per total } \\
\text { taxpayers }(€)\end{array}$ & $\begin{array}{c}\text { Tax } \\
\text { Offices }\end{array}$ & $\begin{array}{l}\text { Ratio of Natural } \\
\text { to Legal entities }\end{array}$ & $\begin{array}{l}\text { Average annual } \\
\text { recovery per total } \\
\text { taxpayers }(€)\end{array}$ \\
\hline F1 & 1.48 & $8,459.1$ & F19 & 0.82 & $20,083.3$ \\
\hline $\mathrm{F} 2$ & 1.94 & 9,7377 & F20 & 0.38 & $12,500.3$ \\
\hline F3 & 1.94 & $8,116.8$ & F21 & 0.18 & $23,110.0$ \\
\hline F4 & 1.46 & $12,208.4$ & F22 & 2.04 & $7,330.5$ \\
\hline F5 & 2.04 & $7,559.8$ & F23 & 0.92 & $8,339.5$ \\
\hline F6 & 1.59 & $13,080.5$ & F24 & 1.92 & $6,936.0$ \\
\hline F7 & 1.62 & $11,768.4$ & F25 & 1.68 & $7,068.2$ \\
\hline F8 & 2.39 & $8,637.4$ & F26 & 1.84 & $6,180.8$ \\
\hline F9 & 1.81 & $8,482.9$ & F27 & 2.08 & $6,268.6$ \\
\hline F10 & 3.93 & $6,411.8$ & F28 & 3.76 & $7,228.7$ \\
\hline F11 & 2.07 & $7,119.1$ & F29 & 2.70 & $6,276.6$ \\
\hline F12 & 1.11 & $7,495.6$ & F30 & 2.54 & $8,340.8$ \\
\hline F13 & 0.63 & $12,842.3$ & F31 & 1.14 & $11,829.9$ \\
\hline F14 & 3.04 & $5,814.3$ & F32 & 2.71 & $11,539.1$ \\
\hline F15 & 1.65 & $9,452.5$ & F33 & 1.69 & $5,926.8$ \\
\hline F16 & 0.77 & $7,964.0$ & F34 & 2.61 & $6,394.9$ \\
\hline F17 & 0.89 & $11,508.1$ & F35 & 0.94 & $15,507.0$ \\
\hline F18 & 0.65 & $12,625.5$ & & & \\
\hline
\end{tabular}

should be sought in specific areas of responsibility and individual tax offices.

Data analysis was based on data envelopment analysis (DEA), a method originating from Farrell's (1957) seminal work, popularised by Charnes, Cooper and Rhodes (1978) and Banker, Charnes and Cooper (1984), that provides a nonparametric alternative to parametric frontier production function analysis.

Our sample data set was analyzed using VRS output-oriented analysis assumption based on Banker, Charnes and Cooper's (1984) previous work, who proposed an extension of the CRS model to explain the cases of variable returns to scale (VRS). It is noted that using the CRS model when all tax offices are not operating under the same return to scale, can lead to unreliable technical efficiency results, not taking into account the scale effects. The literature reveals that for the purpose of estimating tax office performance, only the output-oriented
DEA measures have been empirically estimated (Barros, 2007).

Following Oum and $\mathrm{Yu}$ (1994) and Cantos, Pastor and Serrano (2002) work a two-stage model was applied, which regressed the first-stage DEA efficiency scores (dependent variable) against a selection of independent variables in the second stage. Hence, it is assumed that a significant proportion of the estimated inefficiency of the tax offices under analysis is a result of institutional and environmental/external factors, rather than a product of inefficient management.

Therefore to investigate the extent to which environmental factors influence tax office performance, a Tobit analysis was conducted (Kalina, 2014; McDonald, 2009; Katharaki, 2008; Barros, 2007; Simar and Wilson, 2007; Hoff, 2007; Bravo-Ureta et al. 2007; Latruffe et al., 2004; Fethi, Jackson and Weyman, 2002; Viitala and Hanninen, 1998; Chilingerian, 1995; Bjurek, Kjulin and 
Gustafson, 1992). However, this approach has been recently challenged and found to result in inconsistent and biased parameter estimates, unless the DEA efficiency scores are corrected by a bootstrapping procedure (Merkert et al., 2010). According to Setnitar and Andoljsek (2005), DEA suffers from certain drawbacks, since its main disadvantage originates from its own nonstochastic nature. . In the present study, a bootstrap procedure was used to derive the efficiency scores based on the Simar and Wilson algorithm with some differentiations (Raptis, 2009). All calculations were run by the FEAR 1.12 package for $\mathrm{R}$ software (Wilson, 2008) and our bias-corrected scores are derived from 2000 bootstrap iterations. This way the benchmarking of the tax authorities is achieved under a "quasi" homogenous socio-economic environment, and efforts are focused on the examination of the weaknesses on the side of the management and essentially the degree of tax evasion that results from the way the tax offices operate. In any case, as far as the efficiency of Greek tax offices is concerned, bootstrapping applications that determine efficiency estimates precision are extremely infrequent.

\subsection{Model Inputs and Output Specification}

Based mainly on the data availability and the criteria of Barros (2005), two types of outputs were defined in this paper, namely the incoming taxation revenues related to natural persons $(\mathrm{O} 1)$ and the incoming taxation revenues related to legal entities (O2). The following have been defined in this study as inputs (I):

- I1: labour in each tax office, measured by the number of employees;
- I2: the number of computers operating in each tax office;

- I3: the number of natural persons (NP) paying taxes; and

- I4: the number of legal entities (LE) paying taxes.

Labour was introduced as the key production coefficient in terms of available human resources (I1). The number of computers in each tax office was used as a "proxy" for the available equipment (I2). The choice of natural persons (I3) and legal entities (I4) paying taxes was guided by their impact on the overall service provision and performance of each office, given the different tax legislation which governs them.

\section{RESULTS: \\ MODEL INTERPRETATION \\ 3.1. Efficiency Analysis using DEA and Second Stage Bootstrap approach}

A DEA analysis of the BCC outputoriented model was applied as described above using as output measure the tax revenue collected from natural persons and legal entities. Alternatively, a bootstrap procedure is used where bias-corrected DEA efficiency scores are obtained by means of bootstrap. The results obtained and presented below in Table 2 show the resulting tax offices that operate in a comparatively excellent way (efficiency score $>1$ ). The results are summarised. Detailed performance of individual units, sources of data and the assumptions made in the calculations are available from the author.

According to the $\mathrm{BCC}$ results of Table 2, F7, F19, F21, F32 and F35 tax offices are considered as best-practice units over the specific time period. 
Table 2. Results of DEA and Bootstrap methods

\begin{tabular}{|c|c|c|c|}
\hline Tax Office & $\begin{array}{c}\text { BCC output- } \\
\text { oriented results }\end{array}$ & $\begin{array}{l}\text { Bootstrap results } \\
\text { Mean Efficiency }\end{array}$ & $\begin{array}{l}\% \text { difference on } \\
\text { efficiency scores }\end{array}$ \\
\hline $\mathrm{F} 1$ & 0.63405 & 0.58781 & -7.29 \\
\hline F2 & 0.82761 & 0.82605 & -0.19 \\
\hline F3 & 0.69066 & 0.70323 & 1.82 \\
\hline F4 & 0.97223 & 1.00000 & 2.86 \\
\hline F5 & 0.60029 & 0.43828 & -26.99 \\
\hline F6 & 0.97576 & 0.95812 & -1.81 \\
\hline F7 & 1.00000 & 1.00000 & 0.00 \\
\hline F8 & 0.75404 & 0.70789 & -6.12 \\
\hline F9 & 0.75912 & 0.79388 & 4.58 \\
\hline F10 & 0.66023 & 0.54063 & -18.11 \\
\hline F11 & 0.60485 & 0.49723 & -17.79 \\
\hline F12 & 0.49782 & 0.38126 & -23.41 \\
\hline F13 & 0.77165 & 0.77444 & 0.36 \\
\hline F14 & 0.63008 & 0.61489 & -2.41 \\
\hline F15 & 0.96779 & 0.99569 & 2.88 \\
\hline F16 & 0.58693 & 0.66371 & 13.08 \\
\hline F17 & 0.89842 & 0.96511 & 7.42 \\
\hline F18 & 0.93187 & 0.97291 & 4.40 \\
\hline F19 & 1.00000 & 0.99992 & -0.01 \\
\hline F20 & 0.73107 & 0.71721 & -1.89 \\
\hline F21 & 1.00000 & 1.00000 & -0.00 \\
\hline F22 & 0.66779 & 0.73512 & 10.08 \\
\hline F23 & 0.57909 & 0.52686 & -9.02 \\
\hline F24 & 0.52819 & 0.41422 & -21.58 \\
\hline $\mathrm{F} 25$ & 0.58423 & 0.52937 & -9.39 \\
\hline F26 & 0.53231 & 0.56147 & 5.48 \\
\hline F27 & 0.53311 & 0.53333 & 0.04 \\
\hline F28 & 0.69756 & 0.64962 & -6.87 \\
\hline F29 & 0.60855 & 0.60474 & -0.63 \\
\hline F30 & 0.84268 & 0.84122 & -0.17 \\
\hline F31 & 0.78129 & 0.72585 & -7.10 \\
\hline F32 & 1.00000 & 0.98382 & -1.62 \\
\hline F33 & 0.50252 & 0.55093 & 9.63 \\
\hline F34 & 0.62487 & 0.63758 & 2.03 \\
\hline F35 & 1.00000 & 0.99122 & -0.88 \\
\hline Average & 0.74219 & 0.72639 & $-2.13 \%$ \\
\hline Median & 0.69756 & 0.70789 & $1.48 \%$ \\
\hline Minimum & 0.49782 & 0.38126 & $-23.41 \%$ \\
\hline Stand. Dev. & 0.17232 & 0.19819 & $15.01 \%$ \\
\hline
\end{tabular}

The application of Bootstrap indicates that the tax offices that in comparison make use of their productive factors in the best way are F4, F21, F7, F19 and F15, of which F21, F7, F19, and among the bestfunctioning on the basis the DEA BCC results. In contrast, the group of five most inefficient tax offices according to the
Bootstrap comprises F12, F24, F11, F23 and F25, of which F12 and F24 are within the bottom five based also on the DEA BCC results.

Additionally, the application of bootstrap leads to increased efficiency score in 13 of 35 tax offices in relation to that resulting from the first stage DEA analysis, 
demonstrating that environmental/external factors affect tax office performance and that they could in principle operate effectively, but the general conditions do not allow it. Furthermore, in a greater number of tax offices (20 out of 35) of the sample, applying the bootstrap leads to reduced efficiency scores demonstrating that the "quasi" environment adversely affects performance. For example, F11 has a tax efficiency score equal to 0.60, while the bias-corrected DEA efficiency score is 0.49 meaning that the tax office reduces its income using the same resources. In this context the effect of environmental factors and the reasons behind the drop in revenue should be further examined.

\subsection{Interpretation of Tobit Analysis results}

The results are presented in Table 3 for the year 2006.

Table 3. Censored Tobit Model (dependent variable $y_{i}{ }^{*}$ )

\begin{tabular}{|c|c|}
\hline Variable & $\mathbf{2 0 0 6}$ \\
\hline Constant & 0.59 \\
\hline & $(4.50)^{*}$ \\
\hline $\mathrm{x}_{1}$ & -2.31 \\
\hline & $(8.07)^{*}$ \\
\hline $\mathrm{x}_{2}$ & 1.38 \\
\hline & $(3.56)^{*}$ \\
\hline sigma & 0.43 \\
\hline & \\
\hline Log likelihood & 3.12 \\
\hline Number of observations & 35 \\
\hline
\end{tabular}

Note: the t-statistic in brackets followed by * are significant at $5 \%$.

It follows that the negative and statistically significant values of variable $\mathrm{x}_{1}$ is indicative of the fact that a growing relationship between income per taxpayer, and the average per capita gross product reduces the operational inefficiencies of the tax office. The positive and statistically significant values of variable $\mathrm{x}_{2}$ is indicative of the fact that the increased number of taxpaying legal entities increases the inefficiency of the tax offices, which should be attributed to legal entities making full use of the available legal and accounting framework in order to locate loopholes in the system and evade tax.

\section{DISCUSSION}

The main characteristic of the sample is that all the tax offices therein operate in the broader Attica area, characterized by the complexity of the economic activities of its residents. The diversification of the economic activities is evident in the differences in revenue per tax-paying natural person and legal entity amongst the tax offices in the sample (Table 1).

The DEA BCC results of Table 2 summarize the efficiency score that each tax office reaches, making use of the available productive factors (inputs). In particular and from the output perspective, the top performer achieves twice as much output as the least efficient tax office with the same input. However, these data sets are not dynamic in nature and during the comparative analysis the contribution of the internal and external environment affecting the operation of each tax office is not taken into account. For example, factors like the moral and educational background of the tax office employees is disregarded as are external factors like the ones that contribute to the creation of a tax evasion ethos. 
The use of the Tobit model facilitated the overarching efforts towards investigating and defining parameters/factors that were not taken into account in the DEA but nonetheless are considered as having an impact on the efficiency of each tax office. From the analysis presented above, it was deduced that the increased number of Legal entities (LE) increases in turn the inefficiency of the respective tax office, a fact which can be attributed to the timeconsuming and painstaking handling and processing of LE-related tax issues. This could also be attributed to LE making full use of accounting and legal 'tricks' made possible by the current fiscal institutional framework, thus enabling the development of tax evasion. The analysis illustrated that there are additional parameters to be taken into account given that the sigma coefficient was estimated at 0.43 ; in other words, the independent variables used in the Tobit model 'interpret' the efficiency score only by $43 \%$. In addition, the increased tax revenues with respect to the gross regional product in the area in which the tax office operates limits its inefficiency, since the economic development of the area is harmonized with the associated tax revenues and in turn with the tax office's income. This result is expected since seven (7) of the tax offices, namely F4, F6, F7, F19, F21, F32, F35 display excellent comparative scores as derived from DEA estimates. The average annual per taxpayer recovery of these seven (7) tax offices is higher than 15,057 EUR, comparatively higher than the corresponding value of the sample as a whole, which is set at 9,695,42 EUR. It should also be noted that the Bootstrap estimates show that these seven (7) tax offices display an excellent comparative degree of evaluation. After all, according to Barros (2007) the richer the municipality, the more efficient the tax office.

Given the differences in average revenue among tax offices, the deterministic nature of DEA BCC results and those of Tobit analysis, the method of Bootstrap analysis was used in order to obtain new estimates of performance assessment of tax offices in quasi 'homogeneous' socio-economic environment. From the data in Table 2, which presents the percentage variation between the DEA BCC and Bootstrap results, the following can be discerned:

- 20 of the tax offices display a reduced degree of benchmarking evaluation, 13 of the tax offices of the sample display an increase and two display no change in the extent of benchmarking.

- the maximum negative trend is shown in F5, while the maximum positive development is observed in F16

- the tax offices F21, F7 and F19, and F12 and F24 appear as performing best and worse respectively, compared to other tax offices both at the first stage as well as the second stage bootstrap analysis.

These differences in efficiency scores could be attributed, inter alia, to:

- $\quad$ specific management practices;

- the way the institutional framework is applied, often enabling tax evasion;

- the structure of the economic activities developed in the area of responsibility of each tax office;

- the extent and quality of entrepreneurial taxpayers;

- the sense of civic duty of taxpayers;

- $\quad$ per capita gross national product in the area of responsibility of each tax office, and;

- factors that make up the socioeconomic environment within which the tax offices operate. 
The degree of contribution of these factors varies across location and can greatly impact their operational standing. The biascorrected DEA efficiency scores in a large number of tax offices (20 of 35) are presented at values lower than those obtained by the first-stage DEA BCC analysis. One could say that by applying the Bootstrap and under the assumption that a virtual 'quasi' homogeneous socio-economic operational environment is created, sample tax authorities are shown to operate inefficiently in using their production factors (inputs) to increase revenue from taxpayers (outputs) and thus the need for further investigation into the extent of tax evasion is highlighted. Overall, taking into account that the 'quasi' homogeneous environment has an adverse effect, it is then possible to argue that the inadequate functioning of the tax offices to attain their goals in combination with the tax evasion phenomenon comprise factors that justify the results and can interpret the data sets that emerge.

\section{CONCLUSION AND MANAGERIAL IMPLICATION OF RESEARCH}

The importance of the efficient use of public resources has been brought to the fore by the need to limit expenditure in the public sector. The adequate measurement of public sector efficiency is a difficult empirical issue and the literature on it, particularly when it comes to aggregate and international data, is rather scarce. Measuring and assessing tax offices efficiency is also complicated (Vlasenko, 2001). Tax offices fall under public sector control in the vast majority of national environments. In Greece, tax offices fall under the responsibility and audit of the Ministry of Finance that seeks to enhance accounting control, accountability and tax office performance. In this context, "an efficient tax system is one that minimizes distortions that affect working, saving, investing and entrepreneurship and diverts resources into high productivity uses" (Katsios, 2006). In that sense the main argument for tax reform in Greece is to achieve greater efficiency in the way the tax framework works.

This present study investigated the relative efficiency of 35 Greek tax offices during the period 2001-2006 using a benchmark tool, DEA, and by bootstrapping the DEA results. The main output was the ranking of the tax offices and the identification of those 'efficient' tax offices that might serve as a best-practice benchmark for the inefficient ones. The DEA BCC efficiency scores indicated that a high number of tax offices operate in the appropriate scale size. Additionally, the Tobit analysis revealed that a significant part of the estimated inefficiency of the analyzed tax offices is a result of environmental factors, rather than a product of inefficient management. Moreover, the study overcomes biased related to DEA problems with the application of bootstrap techniques as have been introduced by Simar and Wilson $(1998,2000)$. The implementation of the bootstrap reduces the efficiency score of the tax offices, showing that there are environmental factors that influence tax office performance. And because the estimated model is output oriented (revenue growth) it could be said that such factors relate to issues of resource mismanagement, or to tax evasion.

From a policy perspective, one should be careful when drawing conclusions, since any application of quantitative analysis in decision-making is governed by restrictions, 
especially when complex problems are approached as the question of assessing the performance of tax offices. In this study the combination of DEA and Tobit analysis and the application of Bootstrap analysis tend to approach the issue at hand through the definition of general principles as dictated by conventional policy. The emerging data were used to shed light on "best practice tax offices" used as reference for comparison purposes. Moreover, the findings indirectly highlight the need for measures designed to reduce tax evasion. Specifically, the inefficiency of the tax authorities to fully exploit their available productive factors for the collection of taxes (and consequently the ensuring revenue increase) is made evident from the results of the bootstrap analysis, indicating the inadequacy of the tax offices to serve as efficient tax collection bureaus. In addition, the need to further examine the extent of tax evasion and non-compliance and how these affect the performance of tax offices is also made evident.

Nonetheless, a number of future research initiatives can stem from this present study. More comprehensive input and output measurements, namely, allowing for no discretionary factors, such as socioeconomic and quality inputs and outputs, need to be taken into consideration. A possible direction for further research is also the application of the Malmquist productivity index (Sigbjørn et al., 1991; Bjurek \& Hjalmarsson, 1995; Odeck, 2005), as well as the combination of available techniques in the investigation of tax offices efficiency over a time period. Additionally, despite the limitations related to the data set, the empirical work here suggests that future research may need to concentrate on the dynamic factors i.e. characteristics of the area where the tax office is located or even financial crisis and inflation, which could play a significant role in a tax office performance.

Nevertheless, the general conclusion is that a governance framework within the tax offices, taking into account their characteristics and intending to improve organisational efficiency, is needed. Similar conclusions are also drawn by Barros (2007), who highlighted the need for an organisational government environment, with accountability, transparency and efficiency incentives which explicitly oblige the tax offices to achieve efficiency in their operational activities. Inevitably increasing tax collection by introducing real discernible actions against tax evaders and its impact in tax offices efficiency is an issue which requires further research. Nonetheless, the nature of the economic activities, the characteristics of all taxpayers (natural persons or legal entities), the broader social environment in which the tax offices operate, social realities and other specific characteristics shaping the region in which the tax offices operate impact the effective implementation of the tax system. All of the above may in fact play a decisive role in the creation of a framework that prevents/discourages the violation of the rules of the existing laws, thus limiting tax evasion overall.

\section{Acknowledgements}

The authors would like to thank the reviewer for his/her thorough review and highly appreciate the comments and suggestions on an earlier version of this paper, which significantly contributed to improving the quality of the publication. 


\title{
УТИЦАЈ ФАКТОРА ОКРУЖЕЊА НА ЕФИКАСНОСТ ПОРЕСКИХ ОРГАНИЗАЦИЈА
}

\author{
Marios Tsakas, Maria Katharaki
}

\section{Извод}

Студија проучава перформансе пореских организација у Грчкој. Студија је заснована на подацима добијеним од 35 пореских канцеларија. Евалуација перформанси је урађена уз коришћење ДЕА методе. Поред тога коришћена је Тобит регресиона анализа како би се процениле варијабле окружења које утичу на ефикасност перформанси ових пореских организација. На основу анализе, изведени су закључци о слабостима и начину руковођења који утичу на неефикасност пореских организација. Општи закључак је да робустна управљачка структира, у оквирима операција пореских организација, може довести до унапређења организационе ефикасности.

Кључне речи: Опорезивање, избегавање пореза, менаџмент перформанси, Грчка, ДЕА, Организације јавног сектора, квантитативне методе

\section{References}

Afonso, A., Schuknecht, L., \& Tanzi, V. (2006). Public sector efficiency evidence for new EU member states and emerging markets. Working paper series No 581, European Central Bank, Frankfurt.

Banker, R.D., Charnes, A., \& Cooper, W.W. (1984). Model for estimating technical and scale efficiencies in data envelopment analysis. Management Science, 30(9): 107892.

Barros, C.P. (2005). Performance measurement in tax offices with a stochastic frontier model. Journal of Economic Studies, 32(6): 497-510.

Barros, C.P. (2007). Technical and allocative efficiency of tax offices: a case study. International Journal of Public Sector Performance Management, 1(1): 41-61.

Bjurek, H., Kjulin, U., \& Gustafson, B. (1992). Efficiency, productivity and determinants of inefficiency at public day care centers in Sweden. Scandinavian
Journal of Economics, 94: 173-87.

Bjurek, H., \& Hjalmarsson, L. (1995).

Productivity in multiple output public service: A quadratic frontier function and Malmquist index approach. Journal of Public Economics, 56: 447-460.

Bravo-Ureta, B.E., Solfs, D., Lopez, V.H.M., Maripani, J.F., Thiam, A., \& Rivas, T. (2007). Technical efficiency in farming-a meta-regression analysis. Journal of Productivity Analysis, 27: 37-72.

Budryte, A. (2005). Corporate income taxation in Lithuania in the context of the EU. Research in International Business and Finance, 19(2): 200-28.

Charnes, A., Cooper, W.W., \& Rhodes, E. (1978). Measuring the efficiency of decisionmaking units. European Journal of Operational Research, 2: 429-44.

Cantos, P., Pastor, J.M., \& Serrano, L. (2002). Cost and revenue inefficiencies in the European railways. International Journal of Transport Economics, 29(3): 279-308.

Chilingerian, J.A. (1995). Evaluating 
physician efficiency in hospitals: a multivariate analysis of best practices. European Journal of Operational Research, 80: 548-74.

Farrell, M.J. (1957). The measurement of productive efficiency. Journal of the Royal Statistical Society, Series A, 120(3): 253-90.

Fethi, M.D., Jackson, P.M., \& WeymanJones, T.G. (2002). Measuring the efficiency of European airlines: an application of DEA and tobit analysis. Discussion Paper, University of Leicester, Leicester.

Forsund, F.R., Kittelsen, S.C., \& Lindseth, F. (2005). Efficiency and productivity of Norwegian tax offices. Memorandum 29/2005, Department of Economics, University of Oslo, Oslo.

Gonzalez, M.X., \& Miles, D. (2000). Eficiencia en la Inspeccio'n de Hacienda. Revista de Economia Aplicada, 8(24): 20319.

Hoff, A. (2007). Second stage DEA: comparison of approaches for modelling the DEA score. European Journal of Operational Research, 181: 425-35.

Kalina, J. (2013). Highly Robust Methods in Data Mining. Serbian Journal of Management, 8(1): 9-24.

Katharaki, M. (2008). Approaching the management of hospital units with an operation research technique. The Case of thirty two Greek Obstetric and Gynaecology Public Units. Health Policy, 85(1): 19-31.

Katharaki M., \& Tsakas M. (2010). Assessing the efficiency and managing the performance of Greek Tax-Offices. Journal of Advances in Management Research, 7(1): $58-75$.

Katsios, S. (2006). The shadow economy and corruption in Greece. South-Eastern Europe Journal of Economics, 1: 61-80.

Latruffe, L., Balcombe, K., Davidova, S., \& Zawalinska, K. (2004). Determinants of technical efficiency of crop and livestock farms in Poland. Applied Economics, 36(12): 1255-63.

McDonald, J. (2009). Using least squares and tobit in second stage DEA efficiency analyses. European Journal of Operational Research, 197: 792-8.

Merkert, R., Smith, A.S.J., \& Nash, C.A. (2010). Benchmarking of train operating firms - a transaction cost efficiency analysis. Transportation Planning and Technology, 33(1): 35-53.

Moesen, W., \& Persoon, A. (2002). Measuring and explaining the productive efficiency of tax offices: a non-parametric best practice frontier approach. Tijdschrift Voor Economie en Management, 47(3): 399416.

Odeck, J. (2005). Evaluating target achievements in the public sector: An application of a rare non-parametric DEA and Malmquist indices. Journal of Applied Economics, 8(1): 171-90.

Oum, T.H., \& Yu, C. (1994). Economic efficiency of railways and implications for public policy: a comparative study of the OECD countries' railways. Journal of Transport Economics and Policy , 28(2): 121-138.

Raptis, A. (2009). Stydy of the Implementation of Telemedicine in Greece using numeral, Analytical and Stochastic methods and computational Algorithms. PhD Dissertation, National and Kapodestrian University of Athens, Athens.

Setnikar, S., \& Andoljšek, Z. (2005). Quantitative performance measurement of tax offices in Slovenia. Paper presented at the 13th NISPAcee Annual Conference, Democratic Governance for the XXI Century: Challenges and Responses in CEE Countries, May 19-21, Moscow.

Sigbjørn, B.A., Førsund, F.R., \& Jansen, 
E.S. (1991). Technical efficiency of Norwegian banks: The non-parametric approach to efficiency measurements. Journal of Productivity Analysis, 2: 127-142.

Simar, L., \& Wilson, P.W. (1998). Sensitivity Analysis of Efficiency Scores: How to Bootstrap in Nonparametric Frontier Models. Management Science, 44(1): 49-61.

Simar, L., \& Wilson, P.W. (2000). A general methodology for bootstrapping in non-parametric frontier methods. Journal of Applied Statistics, 27: 779-802.

Simar, L., \& Wilson, P.W. (2007). Estimation and inference in two-stage. semiparametric models of production processes. Journal of Econometrics, 136(1): 31-64.

Thirtle, C., Shankar, B., Chitkara, P., Chatterjee, S., \& Mohanty, M.S. (2000). Size does matter: technical and scale efficiency in Indian State tax jurisdictions. Review of Development Economics, 4(3): 340-52.

Vlasenko, I. (2001). Evaluation of the efficiency and fairness of British, French and Swedish property tax systems. Property Management, 19(5): 384-416.

Viitala, E.-J., \& Hänninen, H. (1998). Measuring the efficiency of public forestry of organizations. Forest Science, 44(2): 298307.

Wilson, P.W. (2008). FEAR: A software package for frontier efficiency analysis with R. Socio-Economic Planning Sciences, 42(4): 247-254. 